\title{
Validation of an ear tag-based accelerometer system for detecting grazing behavior of dairy cows
}

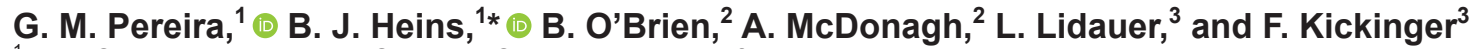 \\ ${ }^{1}$ West Central Research and Outreach Center, University of Minnesota, Morris 56267 \\ ${ }^{2}$ Teagasc, Animal and Grassland Research and Innovation Centre, Moorepark, Fermoy, County Cork, Ireland P61 C996 \\ ${ }^{3}$ Smartbow $\mathrm{GmbH}$, Jutogasse 3, 4675 Weibern, Austria
}

\begin{abstract}
The objective of the study was to develop a grazing algorithm for an ear tag-based accelerometer system (Smartbow GmbH, Weibern, Austria) and to validate the grazing algorithm with data from a noseband sensor. The ear tag has an acceleration sensor, a radio chip, and temperature sensor for calibration and it can monitor rumination and detect estrus and localization. To validate the ear tag, a noseband sensor ( $\mathrm{Ru}-$ miWatch, Itin and Hoch GmbH, Liestal, Switzerland) was used. The noseband sensor detects pressure and acceleration patterns, and, with a software program specific to the noseband, pressure and acceleration patterns are used to classify data into eating, ruminating, drinking, and other activities. The study was conducted at the University of Minnesota West Central Research and Outreach Center (Morris, MN) and at Teagasc Animal and Grassland Research and Innovation Centre (Moorepark, Fermoy, Co. Cork, Ireland). During May and June 2017, observational data from Minnesota and Ireland were used to develop the grazing algorithm. During September 2018, data were collected by the ear tag and noseband sensor from 12 crossbred cows in Minnesota for a total of $248 \mathrm{~h}$ and from 9 Holstein-Friesian cows in Ireland for a total of $248 \mathrm{~h}$. A 2-sided $t$-test was used to compare the percentage of grazing and nongrazing time recorded by the ear tag and the noseband sensor. Pearson correlations and concordance correlation coefficients (CCC) were used to evaluate associations between the ear tag and noseband sensor. The percentage of total grazing time recorded by the ear tag and by the noseband sensor was $37.0 \%$ [95\% confidence interval (CI): 32.1 to 42.0] and $40.5 \%$ (95\% CI: 35.5 to 45.6), respectively, in Minnesota, and $35.4 \%$ (95\% CI: 30.6 to 40.2 ) and $36.9 \%$ (95\% CI: 32.1 to 41.8), respectively, in Ireland. The ear tag and noseband sensor agreed strongly for monitoring
\end{abstract}

Received July 15, 2019.

Accepted December 18, 2019.

*Corresponding author: hein0106@umn.edu grazing in Minnesota ( $\mathrm{r}=0.96 ; 95 \%$ CI: 0.94 to 0.97, $\mathrm{CCC}=0.95)$ and in Ireland $(\mathrm{r}=0.92 ; 95 \% \mathrm{CI}: 0.90$ to $0.94, \mathrm{CCC}=0.92)$. The results suggest that there is potential for the ear tag to be used on pasture-based dairy farms to support management decision-making. Key words: accelerometer, ear tag, validation, grazing

\section{INTRODUCTION}

Precision dairy technologies can be used to reduce farm labor time and aid in farm management (Steeneveld and Hogeveen, 2015). One aspect of management is monitoring animal behavior without disturbing the animal (Müller and Schrader, 2003). Pasture-based dairy production is becoming more common in the United States (USDA, 2016). Therefore, using precision dairy technologies to monitor pasture-based behaviors may provide a potential benefit for grazing-based dairy farms. Furthermore, precision technologies on larger dairy farms may monitor behaviors of animals where human observation may be lacking.

Validation studies with precision dairy technologies have been primarily focused on confinement herds (Bikker et al., 2014; Borchers et al., 2016; Reiter et al., 2018), but recently some research has focused on pasture-based dairy herds (Pereira et al., 2018; Werner et al., 2019). In a grazing dairy herd in the United States, an ear tag accelerometer was used to evaluate behaviors of cows on pasture and showed high correlations for eating $(\mathrm{r}=0.88)$ and rumination $(\mathrm{r}=0.72)$ behavior compared with visual observation (Pereira et al., 2018). In Sweden, a 3-dimensional head-mounted activity logger was placed on 24 Swedish Red cows and, during observations at 5-min intervals of the logger, had a sensitivity (true positive rate) of $86 \%$ for identifying grazing behavior (Nielsen, 2013).

Visual observation is the most common method to validate precision dairy technologies, but it can be laborious and bias may exist between observers (Borchers et al., 2016). In Ireland, a noseband sensor (RumiWatch, Itin and Hoch GmbH, Liestal, Switzerland) was validated by visual observation and had $92 \%$ accuracy 
for recording grazing behavior (Werner et al., 2018). The noseband sensor was validated for eating, ruminating, and drinking by continuous recording in a tiestall barn in Finland. Between continuous recording and the noseband sensor, Ruuska et al. (2016) reported an $\mathrm{R}^{2}$ value of 0.94 for eating, and 0.93 for ruminating and 0.20 for drinking behaviors. Werner et al. (2019) used a noseband sensor to validate grazing and rumination of the MooMonitor + collar (Dairymaster, Tralee, Ireland) and reported high agreement between the noseband sensor and MooMonitor+ with a concordance correlation coefficient of 0.90 . The high-resolution data from the noseband sensor makes it better suited for research purposes than for practical use by dairy farmers (Werner et al., 2019).

An ear tag (Smartbow GmbH, Weibern, Austria) was developed to monitor individual behaviors of cows from ear and head movements and positioning. The ear tag has been validated in confinement herds for rumination time and showed a strong association compared with visual observation in Kentucky ( $\mathrm{r}=0.97$; Borchers et al., 2016) and video recording in Austria ( $\mathrm{r}>$ 0.99; Reiter et al., 2018). The ear tag has potential to detect grazing behavior on pasture-based dairy farms, but validation of the ear tag for grazing behavior has not been conducted. Grazing is a complex behavior to define because cows may walk to an area and stop to eat or continuously walk and take bites of grass from the pasture, while simultaneously ingesting feed (Werner et al., 2018). The objectives of the study were to (1) develop a grazing algorithm for the ear tag, and (2) validate the grazing algorithm for the ear tag in Minnesota and Ireland.

\section{MATERIALS AND METHODS}

This 2-part study was conducted at 2 grazing locations. The first location was the University of Minnesota, West Central Research and Outreach Center, in Morris, Minnesota $\left(45^{\circ} 35^{\prime} 39.12^{\prime \prime} \mathrm{N} ; 95^{\circ} 52^{\prime} 43.36^{\prime \prime} \mathrm{W}\right)$. The grazing herd at the University of Minnesota has 120 milking cows, comprising purebred Holsteins and crossbreds of Holstein, Jersey, Montbéliarde, Normande, and Viking Red. During the summer, other than the $2 \mathrm{~h}$ at milking, the herd had access to pasture full time and the cows were rotationally grazed. The pastures comprised diverse grasses and legumes, including smooth bromegrass (Bromus inermis Leyss.), orchardgrass (Dactylis glomerata), meadow fescue (Festuca pratensis), alfalfa (Medicago sativa), red clover (Trifolium pratense), white clover (Trifolium repens), and kura clover (Trifolium ambiguum Bieb.). Cows were stocked at 3 cows/ ha and rotated to new paddocks every $2 \mathrm{~d}$ based on forage availability. All animal care and management at the grazing dairy in Minnesota was approved by the University of Minnesota Institutional Animal Care and Use Committee (Animal Subjects Code number 150832966A).

The second location was at Teagasc, Animal and Grassland Research and Innovation Centre, Moorepark, Fermoy, County Cork, Ireland (52 $09^{\prime} 47.86^{\prime \prime} \mathrm{N}$; $\left.8^{\circ} 15^{\prime} 44.05^{\prime \prime} \mathrm{W}\right)$. The experimental grazing herd comprised 85 Holstein-Friesian cows. The cows were offered ryegrass (Lolium perenne) pasture full time with a 4-way grazing rotation (A, B, C, D). Cows presented themselves to be voluntarily milked twice per day (approximately) in an automated milking system (AMS, Lely Astronaut A4; Lely Industries N.V., Maassluis, the Netherlands). To assist cow-flow to the AMS, cows moved to a new paddock approximately every $6 \mathrm{~h}$. All animal care and management received ethical approval from the Teagasc Animal Ethics Committee (TAEC119/2016), and procedure authorization was granted by the Irish Health Products Regulatory Authority.

\section{Experiment 1: Development of the Grazing Algorithm}

During May 2017, the Smartbow system was installed in Minnesota and Ireland and ear tags were attached to cows. At the time of installation, the system was not commercially available for monitoring cows on pasture. The ear tag had an acceleration sensor, a radio chip, and temperature sensor for calibration and had a battery life of 2 yr. Ear tags with $10-\mathrm{Hz}$ technology (recording 10 data points per second) were used for data collection but data were later down sampled to 1 $\mathrm{Hz}$. The $10-\mathrm{Hz}$ technology is only used for research purposes and is not commercially available. Data were sent every $3 \mathrm{~s}$ to solar-powered receivers, which captured acceleration data in the pasture where cows grazed through all hours, including the evening and night hours. The solar receivers were permanently installed at a distance of 15 to $20 \mathrm{~m}$ from each other throughout the grazed pastures at both locations. In Minnesota, the solar-powered receivers covered 10 ha, and in Ireland, they covered 23 ha. Data were sent wirelessly from the receivers in the pastures to a server in the dairy barn and further processed and classified into behaviors by proprietary Smartbow algorithms.

Following installation of the ear tag system in Minnesota and in Ireland, visual observation studies were conducted at each location. The data recorded from the observation studies were used to develop the grazing algorithm. Feeding behaviors were grazing, ruminating, and other (Table 1). Grazing was the predominant behavior of interest; this behavior was recorded when a cow had her muzzle close to the ground and ripped 
Table 1. Ethogram and behavior categories

\begin{tabular}{lll}
\hline Category & Behavior & Description of behavior \\
\hline Feeding & Ruminating & $\begin{array}{l}\text { A cow regurgitated a bolus and chewed the cud while moving her head and jaw in a circular motion } \\
\text { and then swallowed the masticated cud }\end{array}$ \\
Grazing & $\begin{array}{l}\text { A cow had her muzzle close to or near the ground and ripped the forage and chewed it (head position } \\
\text { up or down) }\end{array}$ \\
Other & Anything that was not grazing and rumination \\
Lying & A cow with knees bent on the ground \\
& Standing & $\begin{array}{l}\text { A cow had at least } 3 \text { legs on the ground } \\
\text { A cow had continuous leg movement (one foot in front of the other) for at least } 10 \mathrm{~s} \text { with the head } 15 \\
\end{array}$
\end{tabular}

the forage and chewed it (head position up or down). Ruminating was recorded when a cow regurgitated a bolus and chewed the cud, moving her head and jaw in a circular motion, and then swallowed the masticated cud. "Other" was considered anything that was not grazing or ruminating, including sleeping, which was when a cow had her eyes closed, ears down, neck relaxed, and was lying down (Langford et al., 2011; Kull et al., 2019). Locomotion behaviors were walking, standing, and lying. Walking was recorded when the cow had continuous leg movement (one foot in front of the other) for at least $10 \mathrm{~s}$ with the head $15 \mathrm{~cm}$ above the ground. Standing was recorded when the cow had at least 3 legs on the ground. Lying was recorded when the cow was seen with knees bent on the ground.

Feeding and locomotive behaviors (Table 1) were labeled using only one behavior description. For example, if a cow was observed standing and not grazing or ruminating, the behavior was considered "standing feeding other." The behaviors recorded by the observers were standing grazing, standing rumination, standing feeding other, lying grazing, lying rumination, lying sleeping, lying feeding other, walking grazing, walking rumination, and walking feeding other. Behaviors were only recorded if they lasted $>10 \mathrm{~s}$; therefore, observers counted to $10 \mathrm{~s}$ before writing down a behavior. This was crucial for grazing time, because cows were often observed grazing and would lift their head off the ground to move to a new grazing patch within $10 \mathrm{~s}$.

In Minnesota, 3 trained observers recorded behaviors on pasture each day and observed for $6 \mathrm{~h}$ in total per day, from 0730 to $0930 \mathrm{~h}, 1000$ to $1200 \mathrm{~h}$, and 1400 to $1600 \mathrm{~h}$. Interobserver reliability was not collected. Observers did not record behaviors on the same cow and recorded behaviors of different cows each day. Fifteen primiparous and multiparous crossbred cows were used and were sired by Montbéliarde, Normande, Jersey, and
Holstein bulls. Cows were $62 \pm 39$ DIM and averaged $25 \mathrm{~kg}$ of milk/cow per day. Observers were in the same paddock as the cows and were at least $10 \mathrm{~m}$ away from the cows. Observers recorded the start and stop times of each behavior on paper in the pasture and then entered the behaviors manually into an Excel spreadsheet (Microsoft Corp., Redmond, WA). Observers used a digital watch (Timex Group USA Inc., Middlebury, $\mathrm{CT}$ ) that was synchronized with internet time, which was the same time used to synchronize the Smartbow system.

In Ireland, 2 focal cows were observed each day for 11 d by 4 trained observers, and interobserver reliability was not calculated. A pair of 2 observers continuously monitored a different cow from 0930 to $1300 \mathrm{~h}$ and from 1330 to $1700 \mathrm{~h}$, alternating every $30 \mathrm{~min}$ per observer. A total of 21 Holstein-Friesian primiparous and multiparous cows were used and were $49 \pm 17$ DIM. Behaviors were recorded on pasture and during the milking process as some cows used the AMS. Behaviors were entered as start and stop times into a smartphone app linked to internet time. The app was modified for collection of data in the current study by an external company that specialized in digital data collection (Acorn Agricultural Research, Cork, Ireland).

Observational data from Minnesota $(\mathrm{n}=90 \mathrm{~h})$ and Ireland $(\mathrm{n}=150 \mathrm{~h})$ were shared with the manufacturer to develop the grazing algorithm. During development, the dataset from Minnesota and Ireland was split into training and testing data sets to create and internally validate the new algorithm. A confusion matrix (Fielding and Bell, 1997) layout allowed visualization of the performance of the Smartbow grazing algorithm with data from cows in Minnesota and Ireland (Table 2). After development of the algorithm, cows in Minnesota and Ireland were used to validate the algorithm in experiment 2 . 
Table 2. Confusion matrix of the actual and predicted classifications from the ear $\operatorname{tag}^{1}$ grazing algorithm and visual observation data of cows in Minnesota and Ireland ${ }^{2}$

\begin{tabular}{lcc}
\hline & \multicolumn{2}{c}{ Actual classification (visual observation) } \\
\cline { 2 - 3 } $\begin{array}{l}\text { Predicted classification } \\
\text { (Smartbow algorithm) }\end{array}$ & Grazing present & Grazing not present \\
\hline $\begin{array}{l}\text { Grazing present } \\
\text { Grazing not present }\end{array}$ & 112,289 (true positive) & 12,046 (false positive) \\
${ }^{1}$ Smartbow ear tag (Smartbow GmbH, Weibern, Austria). & 112,287 (true negative) \\
\hline $\begin{array}{l}{ }^{2} \text { Data in rows represent the duration (in seconds) that the Smartbow grazing algorithm predicted the grazing } \\
\text { behavior; data in columns represent the duration (in seconds) from the actual visual observation data. }\end{array}$
\end{tabular}

\section{Experiment 2: Validation of the Smartbow Grazing Algorithm}

A noseband sensor (RumiWatch, Itin and Hoch $\mathrm{GmbH}$ ) was used to validate the grazing algorithm because the sensor had high accuracy when previously validated by visual observation of grazing behavior (Werner et al., 2018). The noseband sensor comprised a glycol-filled silicone pressure tube with a built-in pressure sensor and was connected to a data logger on the halter. The data logger was in a protective casing and registered the 3 axis accelerations of the halter and pressure changes in the noseband sensor. The raw data were collected at a frequency of $10 \mathrm{~Hz}$, stored on an SD (Secure Digital) memory card, and transferred to a computer, where data were analyzed and classified into eating, ruminating, drinking, and other activities (Zehner et al., 2017). The time of the noseband sensor was synchronized with internet time. The computer with the Smartbow system was also synchronized with internet time.

\section{Grazing Dairy Cattle and Locations}

In Minnesota, 12 crossbred cows were used for experiment 2 , and ear tags with $10-\mathrm{Hz}$ technology were already attached to the cows at the beginning of the study. Only 4 noseband sensors were available for use, so these were rotated every $4 \mathrm{~d}$ between the 12 cows, and data were recorded from September 7 to 21, 2018. Cows had a 2-d adjustment period to the noseband sensor and $2 \mathrm{~d}$ for collection of data. The noseband sensor was managed and synchronized by the RumiWatch Manager 2 (version 2.2.0.0), and raw data were downloaded to a computer containing RumiWatch software. Raw data were processed by the RumiWatch Converter (version 7.4.5) in 1-min resolution.

The 12 cows were balanced by sire breed (Montbéliarde, Normande, Holstein) and parity (6 primiparous and 6 multiparous). All cows calved during spring 2018 except for one cow that calved during fall 2017. At the beginning of the study date, cows averaged $163 \pm$ 39 DIM and milk yield was $20 \mathrm{~kg} / \mathrm{cow}$ per day. All cows were moved from pasture and milked in a swing9-parabone milking parlor twice per day at 0630 and $1630 \mathrm{~h}$. Cows were not offered grain or TMR in the parlor or on pasture. Cows had free-choice access to minerals from a feeder placed at ground level in each paddock and ad libitum access to a water trough placed at ground level. The average pregrazing height was $24 \mathrm{~cm}$ with $3,796 \mathrm{~kg}$ of $\mathrm{DM} / \mathrm{ha}$ available; the average postgrazing height was $12 \mathrm{~cm}$ with $2,104 \mathrm{~kg}$ of DM/ ha. Grazing height and average forage availability were measured using Electronic Filip's folding plate pasture meter (Jenquip, Feilding, New Zealand), calibrated with regression equations for the Minnesota grazing herd. During the study period, the mean air temperature was $19^{\circ} \mathrm{C}$, and total precipitation was $16 \mathrm{~mm}$.

In Ireland, ear tags with 100-Hz technology and noseband sensors were attached to 9 cows on September 18 and removed from cows on September 26, 2018. Cows had a 2-d adjustment period to the noseband sensor. The noseband sensor was managed and synchronized by RumiWatch Manager 2 (version 2.1.0.0) and raw data were downloaded to a computer with this software. Raw data were processed by the RumiWatch Converter (version 7.4.5) in 1-min resolution.

Cows in Ireland were $206 \pm 20$ DIM at the beginning of the study and averaged $25 \mathrm{~kg}$ of milk/cow per day. Cows were offered $3 \mathrm{~kg} / \mathrm{d}$ of concentrates in the AMS. The average DM content of the ryegrass was $19 \%$ and the average pregrazing height was $10 \mathrm{~cm}$ with $1,330 \mathrm{~kg}$ of DM/ha available, and a postgrazing height of $4 \mathrm{~cm}$. Grazing height and forage availability were measured by the Grasshopper Rising plate meter (True North Technologies, Shannon, Ireland; diameter $355 \mathrm{~mm}$, plate weight $4.785 \mathrm{~kg}$ ). Across the study period, mean air temperature was $11^{\circ} \mathrm{C}$ and total precipitation was $25 \mathrm{~mm}$.

\section{Data Collection and Processing}

Smartbow GmbH provided ear tag data from cows in Minnesota and Ireland from the respective study periods during September 2018. The study periods 
(date and time of data for cows) from both locations were requested by the main author (GMP); therefore, Smartbow staff were blinded to which data and cows were used for analysis. These data were provided in minutes, and every minute was classified as grazing, nongrazing, or undefined. Subsequently, the data were summarized into 1-h summaries by cow per day per location. "Undefined" behaviors were uncaptured data from when cows were outside the solar receiver coverage area on pasture. These data could not be further classified, so 1-h summaries that included undefined behaviors were removed from analysis. Out of the total observation time from both locations, $54 \%(1,184 \mathrm{~h})$ had minutes that were considered undefined behavior. Because of the undefined behaviors, not all cows contributed the same number of hours to the final data sets. In Minnesota, cows provided from 6 to $34 \mathrm{~h}$ of data, and in Ireland, from 15 to 39 h. Hour summaries only included the number of minutes spent grazing and nongrazing for each cow.

The noseband sensor data were analyzed by the $\mathrm{Ru}-$ miWatch Converter (version 7.4.5) in 1-min resolution, and every minute was classified as ruminate, eat head up, eat head down, drinking, grazing bites, and other (Jessica Werner, University of Hohenheim, Stuttgart, Germany; personal communication). If a cow had her head up or down but was not grazing, the time was considered "other." For comparison with ear tag data, minutes that were classified as eat up, eat down, or grazing bites were considered grazing, whereas minutes that were classified as ruminate, drinking, or other were considered nongrazing. Then, minute data were summarized into hour summaries by cow per day per location.

Hour summary data from the ear tag and the noseband sensor were matched by cow per hour per day per location into one Excel 2016 spreadsheet (Microsoft Corp., Redmond, WA). In Minnesota and Ireland, 248 and $778 \mathrm{~h}$, respectively, were available for comparing ear tag data with noseband sensor data. More hours were available in Ireland because they had more noseband sensors and because the grazing season in Minnesota was ending during the study period.

Because the objective of the study was to validate grazing behavior, agreement between the ear tag and noseband sensor for grazing-intensive and non-grazingintensive hours was also evaluated. The average time spent grazing $(\mathrm{min} / \mathrm{h})$ were calculated for each location (PROC MEANS of SAS; SAS Institute Inc., 2016). If cows grazed for more than $50 \%$ of the hour $(\geq 30$ min), that hour was considered grazing intensive. Selecting the predominant behavior observed per hour has been used in previous studies. In 2 accelerometer validation studies, the predominant behavior by visual observation was considered the behavior recorded for more than $30 \mathrm{~s}$ (50\% of the time) during each minute (Delagarde and Lamberton, 2015; Pereira et al., 2018). The Ireland herd was not on a regular milking schedule like the Minnesota herd; rather, cows chose the time to be voluntarily milked by the AMS and were allowed to move to a new paddock every $6 \mathrm{~h}$. Because of this herd management, if the $\geq 30 \mathrm{~min} / \mathrm{h}$ method had been applied to the Ireland herd, only $3 \mathrm{~h}(1000,1500$, and 2000 h) would be considered grazing intensive. Because cows graze on average $8 \mathrm{~h} / \mathrm{d}$ (Kilgour, 2012), $8 \mathrm{~h}$ per location were selected as grazing-intensive and the remaining $16 \mathrm{~h}$ considered non-grazing-intensive. Therefore, the threshold that allowed for $8 \mathrm{~h}$ of the day to be considered grazing-intensive was $\geq 26 \mathrm{~min}$. If cows grazed for $\geq 26 \mathrm{~min} / \mathrm{h}$ in Ireland, those hours were considered grazing-intensive. In Minnesota, the following hours were considered grazing-intensive: 0800, 0900, 1000, 1100, 1200, 1500, 1800, $1900 \mathrm{~h}$; all other hours were non-grazing-intensive. In Ireland, the grazing-intensive hours were 0700, 1000, 1100, 1300, 1400, 1500, 1600, and $2000 \mathrm{~h}$; all other hours were non-grazing-intensive.

\section{Statistical Analysis}

In experiment 1 , the rows in the confusion matrix represented the duration (in seconds) that the Smartbow grazing algorithm predicted grazing behavior, and the columns represented the duration (in seconds) from the actual visual observation data. In the matrix, the 4 possible outcomes were true positive (TP, grazing was present for both the Smartbow ear tag and visual observation), false positive (FP, grazing was present for the Smartbow ear tag but not present by visual observation), false negative (FN, grazing was not present for the Smartbow ear tag but was present by visual observation), and true negative ( $\mathbf{T N}$, grazing was not present for both the Smartbow ear tag and visual observation $)$. Precision $[\mathrm{TP} /(\mathrm{TP}+\mathrm{FP}) \times 100]$, recall $[\mathrm{TP} /(\mathrm{TP}+\mathrm{FN}) \times 100]$, and accuracy $[\mathrm{TP}+\mathrm{TN} /(\mathrm{TP}$ $+\mathrm{TN}+\mathrm{FP}+\mathrm{FN}) \times 100]$ were calculated to determine agreement between the Smartbow ear tag grazing algorithm and visual observation.

In experiment 2, data from Minnesota and Ireland were analyzed separately. Because more hours were available for analysis in Ireland and to maintain consistency with the $248 \mathrm{~h}$ from Minnesota, $248 \mathrm{~h}$ from the 778-h Ireland data set were chosen by random number generator for analysis of the Ireland data (PROC SURVEY of SAS; version 9.4). To prevent bias in the data chosen by the random number generator, 3 data sets were generated at random. Therefore, the hours $(\mathrm{n}=$ 248) selected for each data set from the original Ireland data set of $778 \mathrm{~h}$ were not the same across the data 
sets. Analysis on each data set was done separately and the results were averaged.

The UNIVARIATE procedure of SAS 9.4 (SAS Institute, 2016) was used to establish normality. A 2 -sided $t$-test, calculated with PROC TTEST of SAS 9.4 (SAS Institute, 2016), compared the percentage of time each cow's behavior was recorded by the ear tag and the noseband sensor for the overall total time of 248 h. Pearson correlations were calculated with PROC CORR of SAS 9.4 (SAS Institute, 2016) to evaluate associations between the ear tag and the noseband sensor. The epiR package of $\mathrm{R}$ software ( $\mathrm{R}$ version 3.3.1; https://www.r-project.org/) was used to calculate the concordance correlation coefficient (CCC; Lin, 1989), bias correction factors, location shift, and scale shift between the ear tag and the noseband sensor. Pearson correlations were considered negligible (0.0 to 0.3), low (0.3 to 0.5$)$, moderate (0.5 to 0.7 ), high (0.7 to 0.9 ), or very high (0.9 to 1.0; Hinkle et al., 2003). Statistical significance was considered at $P<0.05$.

Bland-Altman plots (Appendix Figures A1, A2, A3, A4, and A5) were created with PROC SGPLOT of SAS 9.4 (SAS Institute, 2016) to indicate the mean difference between the ear tag and the noseband sensor in grazing minutes/hour and their associated 95\% limits of agreement (Bland and Altman, 1995). The limits of agreement were calculated as \pm 1.96 standard deviations from the bias.

\section{RESULTS AND DISCUSSION}

For experiment 1, agreement between the ear tag grazing algorithm and visual observation data had precision, recall, and accuracy of 90, 92, and 91\%, respectively (Table 2). Reiter et al. (2018) had the same objectives as the current study in a confinement dairy herd using the same ear tag and developed and tested an algorithm for rumination behavior for a total of 100 h. In that study, the correlation between the ear tag algorithm and video recording for rumination time was
0.99 (Reiter et al., 2018). The noseband sensor used in the current study has been validated by visual observation for grazing beef cattle in Italy. The noseband sensor had precision of $88 \%$ and accuracy of $89 \%$ for feeding behavior compared with direct visual observation, which are similar values to those of the current study (Poulopoulou et al., 2019). A different ear tag accelerometer (CowManager SensOor; Agis Automatisering BV, Harmelen, the Netherlands) was validated for feeding and rumination in Canadian feedlot cattle by visual observation. The recall and precision of the ear tag accelerometer was 95 and 60\%, respectively (Wolfger et al., 2015). The precision, recall, and accuracy were $\geq 90 \%$.

For experiment 2, the average percentage of total time $(\mathrm{n}=248 \mathrm{~h})$, median, and $95 \%$ CI for grazing and nongrazing behaviors recorded by the ear tag and the noseband sensor are shown in Table 3. For Minnesota, the percentage of daily grazing time was $37.0 \%$ (95\% CI: 32.1 to 42.0 ) recorded by the ear tag and $40.5 \%(95 \%$ CI: 35.5 to 45.6 ) by the noseband sensor. The noseband sensor recorded daily grazing time 3.5 percentage units longer $(P<0.01)$, on average, than the ear tag. A mean bias of $-2.1 \mathrm{~min} / \mathrm{h}$ was observed when agreement was compared between the ear tag and noseband sensor for grazing $(\mathrm{min} / \mathrm{h})$ from the Bland-Altman plot (Appendix Figure A1). The mean bias indicates that the noseband sensor measured grazing for longer than the ear tag. The $95 \%$ limits of agreement ranged from -16 and $12 \mathrm{~min} / \mathrm{h}$. Additionally, in Minnesota, the ear tag recorded nongrazing time for $63.0 \%$ (95\% CI: 58.0 to $67.9)$, whereas the noseband sensor recorded nongrazing time for $59.5 \%$ (95\% CI: 54.4 to 64.5 ).

In Ireland, the percentage of daily grazing time was $35.4 \%$ (95\% CI: 30.6 to 40.2 ) recorded by the ear tag and $36.9 \%$ (95\% CI: 32.1 to 41.8 ) by the noseband sensor. The ear tag recorded nongrazing time for $64.6 \%$ (95\% CI: 59.8 to 69.4 ) and the noseband sensor recorded nongrazing time for $63.1 \%$ (95\% CI: 58.2 to 67.9 ) in Ireland. The Bland-Altman plot (Appendix Figure

Table 3. Average percentage of time \pm standard deviation (calculated with a 2 -sided paired $t$-test) for each specific behavior from the total recorded time of $248 \mathrm{~h}$

\begin{tabular}{|c|c|c|c|c|c|c|c|}
\hline \multirow[b]{2}{*}{ Location and behavior } & \multicolumn{3}{|c|}{ Ear tag ${ }^{1}$} & \multicolumn{3}{|c|}{ Noseband sensor $^{2}$} & \multirow[b]{2}{*}{$P$-value } \\
\hline & Total time & Median & $95 \% \mathrm{CI}$ & Total time & Median & $95 \% \mathrm{CI}$ & \\
\hline Grazing & $37.0 \pm 39.6$ & 25.0 & $32.1-42.0$ & $40.5 \pm 40.2$ & 28.0 & $35.5-45.6$ & 0.01 \\
\hline Nongrazing & $63.0 \pm 39.6$ & 75.0 & $58.0-67.9$ & $59.5 \pm 40.2$ & 72.0 & $54.4-64.5$ & 0.01 \\
\hline \multicolumn{8}{|l|}{ Ireland } \\
\hline Grazing & $35.4 \pm 38.4$ & 18.6 & $30.6-40.2$ & $36.9 \pm 38.8$ & 20.8 & $32.1-41.8$ & 0.25 \\
\hline
\end{tabular}

${ }^{1}$ Smartbow ear tag (Smartbow GmbH, Weibern, Austria).

${ }^{2}$ RumiWatch noseband sensor (Itin + Hoch GmbH, Liestal, Switzerland). 
A2) for Ireland had a mean bias of $0.49 \mathrm{~min} / \mathrm{h}$, which indicated that the ear tag measured grazing for longer than the noseband sensor. The $95 \%$ limits of agreement ranged from -20 to $19 \mathrm{~min} / \mathrm{h}$.

Appendix Figures A1 to A5 show Bland-Altman plots indicating the mean difference between the ear tag and noseband sensor for grazing (in $\mathrm{min} / \mathrm{h}$ ) in Minnesota and Ireland from experiment 2. The mean differences for grazing were $-2.1 \pm 7.06 \mathrm{~min} / \mathrm{h}$ in Minnesota $(\mathrm{n}=$ 248); $0.49 \pm 9.73 \mathrm{~min} / \mathrm{h}$ in Ireland (complete data set; $\mathrm{n}=778) ;$ and $-0.45 \pm 9.75 \mathrm{~min} / \mathrm{h}(\mathrm{n}=248$ data set 1$)$, $-1.6 \pm 7.94 \mathrm{~min} / \mathrm{h}(\mathrm{n}=248$ data set 2$)$, and $-0.67 \pm$ $9.41 \mathrm{~min} / \mathrm{h}(\mathrm{n}=248$ data set 3$)$ for the randomly generated datasets in Ireland. In the Bland-Altman plots in the Appendix, the calculated mean differences between the ear tag and noseband sensor for grazing were within the $95 \%$ CI and most of the data points surrounded the zero line. Therefore, there was high agreement between the ear tag and noseband sensor for monitoring grazing behavior in Minnesota and Ireland. Additionally, fewer mean difference values were outside the $95 \%$ CI in Appendix Figures A3 to A5, which represent the data sets that included only the $248 \mathrm{~h}$ from the complete Ireland data in Appendix Figure A2 $(\mathrm{n}=778)$. Because these hours were selected from the original Ireland data set of $778 \mathrm{~h}$, the hours are not the same across data sets; therefore, different values are observed in Appendix Figures A3 to A5.

In this study, undefined behaviors in the data occurred when cows were outside the solar receiver coverage area on pasture. In Minnesota, the pasture where cows grazed is not flat, and the hills represent one limitation of using an outdoor location system.

In Finland, cows in a tiestall were used to validate the noseband sensor for eating, ruminating, and drinking by continuous video recording. Similar to the current study, eating time was slightly overestimated $(P<0.06)$ by the noseband sensor $(3.8 \pm 0.80 \mathrm{~h} / 12 \mathrm{~h})$ compared with continuous recording $(3.2 \pm 0.54 \mathrm{~h} / 12 \mathrm{~h}$; Ruuska et al., 2016). In the same Irish herd as used the current study, the noseband sensor validated the MooMonitor+ collar for grazing and ruminating. The noseband sensor recorded grazing for $576 \mathrm{~min} / \mathrm{d}$, on average, and the collar recorded grazing for $513 \mathrm{~min} / \mathrm{d}$ (Werner et al., 2019). The main behaviors of pasture-based dairy cattle are grazing and resting, and cows will graze on average for 480 min during the day (Kilgour, 2012). In the current study, grazing was recorded on average across both locations for $532 \mathrm{~min}$ of the total recorded time or $38 \%$ of the total time (Table 3). The total recorded time of $38 \%$ in the current study is similar to that of a study in Spain, in which grazing behavior recorders showed that cows averaged $522 \mathrm{~min}$ or $36 \%$ of their day grazing (Roca-Fernández et al., 2013).
The average grazing times $(\mathrm{min} / \mathrm{h})$ recorded by ear tag and noseband sensor throughout the day are shown in Figures 1 and 2, for Minnesota and Ireland, respectively. Cows in Minnesota averaged $50 \mathrm{~min}$ or more grazing during the hours beginning at 0800, 1800, and $1900 \mathrm{~h}$, as recorded by both technologies. During the hours beginning at 1000, 1500, 1600, and $2000 \mathrm{~h}$, cows in Ireland spent almost the entire hour grazing, as recorded by both technologies. Pasture-based dairy cattle usually consume the majority of their meals near sunrise and sunset (Gregorini et al., 2006); in Minnesota during the study period, sunrise was at $0700 \mathrm{~h}$ and sunset at $1930 \mathrm{~h}$. Cows in Minnesota were milked in the morning around sunrise; therefore, cows started grazing after milking at $0800 \mathrm{~h}$. During the evening, cows in Minnesota grazed immediately before sunset at 1800 $\mathrm{h}$ and stopped around $2000 \mathrm{~h}$. In Ireland during the study period, sunrise was at $0720 \mathrm{~h}$ and sunset at 1930 h. Cows in Ireland grazed throughout the day; around $2000 \mathrm{~h}$, close to sunset, they stopped grazing and did not graze much during the nighttime hours.

Gibb et al. (1998) reported that cows grazed for longer beginning at $0700 \mathrm{~h}, 1130 \mathrm{~h}$, and $1600 \mathrm{~h}$, with the highest intake of pasture at $0700 \mathrm{~h}$. In the current study, there was a clear grazing pattern for cows in Minnesota. Cows grazed after each milking time, at 0630 and $1630 \mathrm{~h}$. During the nighttime period in Minnesota, from 2000 to $0800 \mathrm{~h}$, the average time that cows spent grazing ranged from 0 to $31 \mathrm{~min} / \mathrm{h}$, as recorded by ear tag, and from 0 to $35 \mathrm{~min} / \mathrm{h}$, as recorded by the noseband sensor. Starting between 0800 and 2000 $\mathrm{h}$, the average time that cows spent grazing ranged from 0 to $56 \mathrm{~min} / \mathrm{h}$ (ear tag) and from 6 to $58 \mathrm{~min} / \mathrm{h}$ (noseband sensor). Conversely, in Ireland, the grazing pattern was not clearly defined because cows were not milked at the same time every day by the AMS. In Ireland, between 2000 and $0800 \mathrm{~h}$, the average time cows spent grazing ranged from 3 to $35 \mathrm{~min} / \mathrm{h}$ (ear tag) and from 1 to $37 \mathrm{~min}$ (noseband sensor). However, between 0800 and $2000 \mathrm{~h}$, the average time cows spent grazing ranged from 19 to $46 \mathrm{~min} / \mathrm{h}$ (ear tag) and from 23 to 44 min/h (noseband). In a New Zealand Holstein Friesian grazing herd, Fisher et al. (2008) reported that cows spent $234 \mathrm{~min}$ grazing from 0930 to $1430 \mathrm{~h}$ and $207 \mathrm{~min}$ grazing from 1530 to $2000 \mathrm{~h}$. During the night period, from 2030 to $0650 \mathrm{~h}$, cows predominantly lay down, and grazing time ranged from 4 to $38 \mathrm{~min}$ (Fisher et al., 2008).

Table 4 shows correlations, bias correction factor, location shift, and scale shift of the ear tag compared with the noseband sensor for grazing in Minnesota and Ireland. The correlation of grazing and nongrazing behavior was $0.92(P<0.01$; CCC $=0.92)$ between the ear tag and noseband sensor in Ireland, and $0.96(P$ 


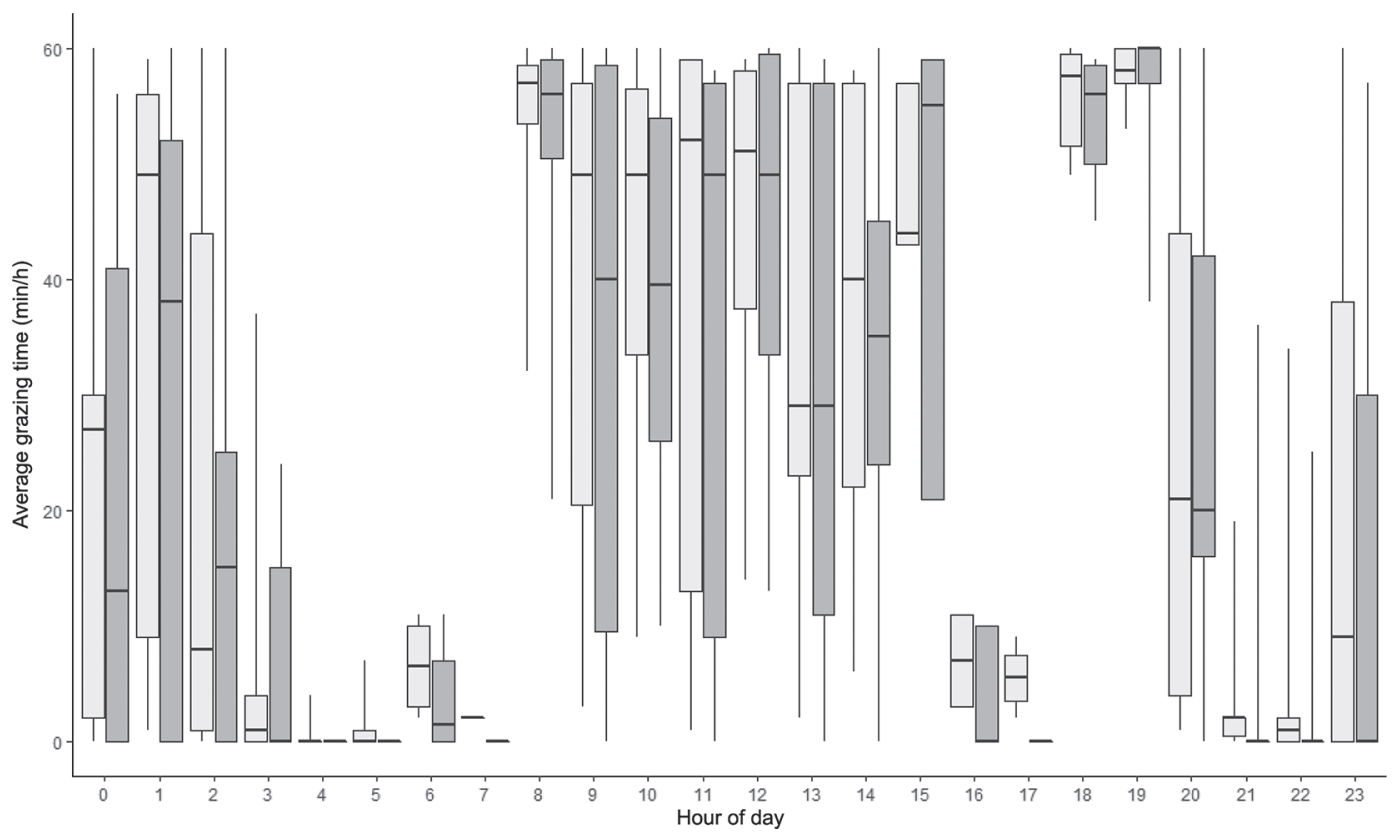

Figure 1. Boxplots of average grazing time $(\mathrm{min} / \mathrm{h} ; \mathrm{n}=248)$ by hour of day in Minnesota recorded by the noseband sensor (light gray; RumiWatch noseband sensor, Itin + Hoch GmbH, Liestal, Switzerland) and the ear tag (dark gray; Smartbow ear tag, Smartbow GmbH, Weibern, Austria). The bottom and top of the box are the first and third quartiles; the heavy black horizontal lines are the median; and the whiskers correspond to the $1.5 \times$ interquartile range.

$<0.01 ; \mathrm{CCC}=0.95)$ in Minnesota. The location shift for grazing was -0.04 in Ireland and -0.09 in Minnesota; for nongrazing, it was 0.04 in Ireland and 0.09 in Minnesota. Location shifts closer to zero are preferred, whereas a scale shift closer to 1 is preferred. The results for location and scale shift across both locations were very close to the desired values (Table 4). The location shift for grazing was lower in Ireland $(-0.04)$ than in Minnesota (-0.09). In Ireland, the correlation and CCC were the same (0.92), which is why the scale shift was almost 1 (0.99). In Minnesota, the scale shift was 0.98 but the correlation and CCC were not equal $(\mathrm{r}=$ 0.96 ; CCC $=0.95$ ).

The results of the current study are similar to those of Pereira et al. (2018), who found eating behavior recorded by direct visual observations and a different ear tag accelerometer to be highly correlated $(\mathrm{CCC}=0.88)$ for pasture-based dairy cattle in a Minnesota grazing herd. The noseband sensor was used to validate the MooMonitor + collar (Dairymaster) for grazing behavior (Werner et al., 2019), and a high correlation was reported between the noseband sensor and the collar $(\mathrm{CCC}=0.95)$, which is the same as the CCC reported in the current study for Ireland.

Table 5 shows the Pearson correlations of grazing-intensive hours recorded by the ear tag and the noseband sensor at both grazing locations. In Minnesota, during the hours beginning at 0800, 0900, 1000, 1100, 1200, 1500,1800 , and $1900 \mathrm{~h}$, grazing was recorded by both devices for $\geq 30 \mathrm{~min} / \mathrm{h}$ on average. In Minnesota, the grazing-intensive correlation was $0.89(P<0.01)$ and the CCC was 0.89; for the non-grazing-intensive hours, the correlation was $0.95(P<0.01)$ and the CCC was 0.95. Similarly, in Ireland, during the hours beginning

Table 4. Results of a validation study with Pearson correlation coefficient, bias correction factor, concordance correlation coefficient (CCC), location shift, and scale shift of the ear $\operatorname{tag}^{1}$ compared with the noseband sensor ${ }^{2}$ for grazing behaviors in Minnesota and Ireland ${ }^{3}$

\begin{tabular}{lcccccccc}
\hline & & & & & & \multicolumn{2}{c}{ Location shift } \\
\cline { 5 - 8 } Location & Correlation & $95 \%$ CI & P-value & $\begin{array}{c}\text { Correction } \\
\text { bias }\end{array}$ & CCC & Grazing & Nongrazing & Scale shift \\
\hline Minnesota & 0.96 & 0.94 to 0.97 & $<0.001$ & 1.00 & 0.95 & -0.09 & 0.09 & 0.98 \\
Ireland & 0.92 & 0.90 to 0.94 & $<0.001$ & 1.00 & 0.92 & -0.04 & 0.04 & 0.99 \\
\hline
\end{tabular}

${ }^{1}$ Smartbow ear tag (Smartbow GmbH, Weibern, Austria).

${ }^{2}$ RumiWatch noseband sensor (Itin + Hoch GmbH, Liestal, Switzerland).

${ }^{3}$ Data recorded by both technologies were compared on an hourly basis ( $\mathrm{n}=248 \mathrm{~h}$ per location). 
Table 5. Pearson correlations and concordance correlation coefficients (CCC) of the ear $\operatorname{tag}^{1} \operatorname{compared~with~the~noseband~sensor~}^{2}$ for hours of the day considered grazing-intensive and non-grazing-intensive in Minnesota and Ireland

\begin{tabular}{|c|c|c|c|c|c|}
\hline Location & Item & Correlation & $95 \% \mathrm{CI}$ & $P$-value & $\mathrm{CCC}$ \\
\hline \multirow[t]{2}{*}{ Minnesota $^{3}$} & Grazing-intensive & 0.89 & $0.83-0.93$ & 0.01 & 0.87 \\
\hline & Non-grazing-intensive & 0.95 & $0.93-0.96$ & 0.01 & 0.95 \\
\hline Ireland $^{4}$ & Grazing-intensive & 0.86 & $0.80-0.91$ & 0.01 & 0.86 \\
\hline
\end{tabular}

${ }^{1}$ Smartbow ear tag (Smartbow GmbH, Weibern, Austria).

${ }^{2}$ RumiWatch noseband sensor (Itin + Hoch GmbH, Liestal, Switzerland).

${ }^{3}$ Minnesota grazing hours (beginning at): 0800, 0900, 1000, 1100, 1200, 1500, 1800, and 1900 h; nongrazing hours: 0000, 0100, 0200, 0300, 0400, 0500, 0600, 0700, 1300, 1400, 1600, 1700, 2000, 2100, 2200, and $2300 \mathrm{~h}$.

${ }^{4}$ Ireland grazing hours (beginning at): 0700, 1000, 1100, 1300, 1400, 1500, 1600, and $2000 \mathrm{~h}$; nongrazing hours: 0000, 0100, 0200, 0300, 0400, 0500, 0600, 0800, 0900, 1200, 1700, 1800, 1900, 2100, 2200, and $2300 \mathrm{~h}$.

at $0700,1000,1100,1300,1400,1500,1600$, and 2000 $\mathrm{h}$, grazing was recorded by both devices for $>26 \mathrm{~min} / \mathrm{h}$ on average. In Ireland, the grazing-intensive correlation was $0.86(P<0.01)$ and the CCC was 0.86 ; the non-grazing-intensive correlation was $0.95(P<0.01)$ and the CCC was 0.94. Agreement between the ear tag and noseband pressure sensor was lower for grazingintensive hours (Minnesota: 0.89, Ireland: 0.86) than overall (Minnesota: 0.96, Ireland: 0.92).

A study in France kept cows on pasture for different hours of the day and compared their daily grazing behavior. Cows that were on pasture for most of the day grazed immediately after the morning and evening milkings for 45 to $55 \mathrm{~min} / \mathrm{h}$ and had little grazing ac- tivity in the afternoon (30 to $35 \mathrm{~min} / \mathrm{h}$ ) or at night. However, cows that grazed for the $9 \mathrm{~h}$ between morning and evening milkings had an intense grazing bout for 55 to $60 \mathrm{~min} / \mathrm{h}$ after morning milking and an intense grazing bout of $50 \mathrm{~min} / \mathrm{h}$ before the evening milking (PérezRamírez et al., 2009). Similar to the unrestricted group in the aforementioned study, cows in Minnesota were fetched for milking in the parlor and returned to pasture at similar times every day. The grazing-intensive hours in Minnesota were evident because there were more hours in Minnesota with a threshold of grazing $\geq 30$ min. During these hours, the cows grazed and did not display other behaviors. Cows in Minnesota grazed for 1 to $2 \mathrm{~h}$ after the morning and night milking times

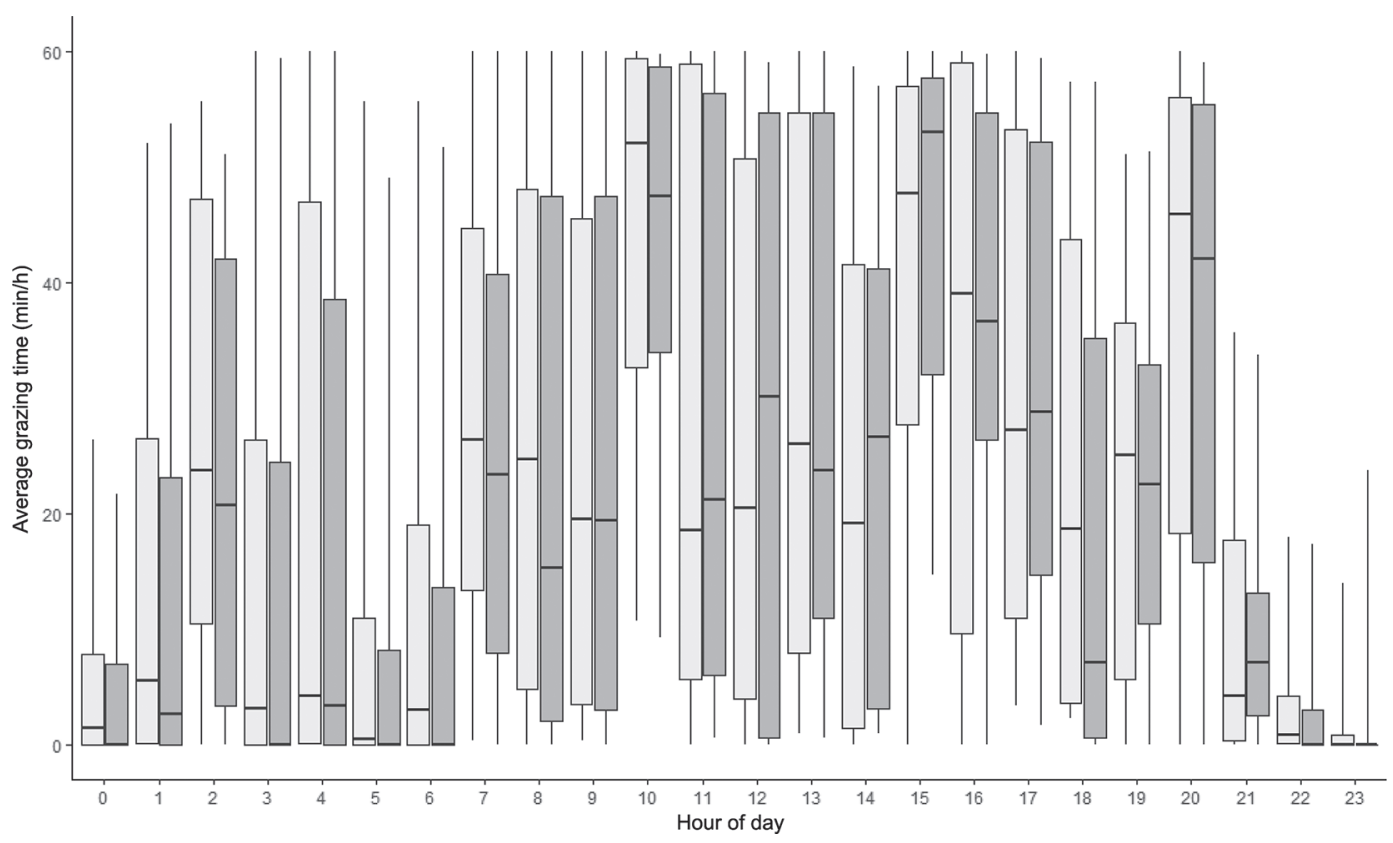

Figure 2. Boxplots of average grazing time $(\mathrm{min} / \mathrm{h} ; \mathrm{n}=248)$ by hour of day in Ireland recorded by the noseband sensor (light gray; RumiWatch noseband sensor, Itin + Hoch GmbH, Liestal, Switzerland) and the ear tag (dark gray; Smartbow ear tag, Smartbow GmbH, Weibern, Austria). The bottom and top of the box are the first and third quartiles; the heavy black horizontal lines are the median; and the whiskers correspond to the $1.5 \times$ interquartile range. 
consistently every day, whereas cows in Ireland were rotated every $6 \mathrm{~h}$ to a new paddock. These management conditions may explain why the correlation for grazing-intensive hours was slightly higher in Minnesota $(\mathrm{r}=0.89)$ than in Ireland $(\mathrm{r}=0.86)$. Additionally, in the study where the noseband sensor validated the MooMonitor+ collar for grazing, higher correlations were reported for the noseband sensor and the collar for grazing behavior in 1-h summaries compared with 15 -min summaries $(\mathrm{CCC}=0.95$ for $15 \mathrm{~min}$; $\mathrm{CCC}=$ 0.97 for 1-h summaries; Werner et al., 2019). Because more grazing-intensive hours in Minnesota were $\geq 30$ min, there is potential for agreement between the ear tag and noseband sensor to be higher in Minnesota than in Ireland.

\section{CONCLUSIONS}

Implementing technologies on pasture-based dairy farms has been slow, but being able to monitor grazing behavior and other activities is as important on pasture as it is on confinement farms. The ear tag and noseband sensor were in agreement when they recorded total grazing time, and high agreement was reached for grazing behavior and for grazing intensive hours. Our results suggest that the ear tag can accurately monitor grazing behavior in pasture-based dairy farms. It was appropriate to use the noseband sensor to validate the Smartbow grazing algorithm to reduce the variability across observers at both locations. The Smartbow grazing algorithm is not commercially available yet, but there is great potential for pasture-based dairy farms to use the ear tag to support farm management decisionmaking. Further research with this ear tag should focus on using data to ensure welfare of grazing animals.

\section{ACKNOWLEDGMENTS}

The authors in Minnesota thank Darin Huot and coworkers at University of Minnesota West Central Research and Outreach Center (Morris, MN) for their assistance and care of the animals. This work was supported by Organic Agriculture Research and Extension Initiative (grant no. 2012-51300-20015/project accession no. 0230589) from the USDA National Institute of Food and Agriculture (Washington, DC). The authors in Ireland gratefully acknowledge Science Foundation Ireland for funding the project "Precision Dairy." Laura Lidauer and Florian Kickinger had no financial relationships with the other authors because the Smartbow system was purchased and is owned by researchers at the individual locations. Lidauer and Kickinger participated in the algorithm development of the Smartbow system but did not participate in data collection methods or the data analyses. The content and results reported in this manuscript were chosen by Glenda Pereira, Brad Heins, and Bernadette O'Brien.

\section{REFERENCES}

Bikker, J. P., H. van Laar, P. Rump, J. Doorenbos, K. van Meurs, G. M. Griffioen, and J. Dijkstra. 2014. Technical note: Evaluation of an ear-attached movement sensor to record cow feeding behavior and activity. J. Dairy Sci. 97:2974-2979. https://doi.org/10.3168/ jds.2013-7560.

Bland, J. M., and D. G. Altman. 1995. Comparing methods of measurement: Why plotting difference against standard method is misleading. Lancet 346:1085-1087. https://doi.org/10.1016/S0140 -6736(95)91748-9.

Borchers, M. R., Y. M. Chang, I. C. Tsai, B. A. Wadsworth, and J. M. Bewley. 2016. A validation of technologies monitoring dairy cow feeding, ruminating, and lying behaviors. J. Dairy Sci. 99:74587466. https://doi.org/10.3168/jds.2015-10843.

Delagarde, R., and P. Lamberton. 2015. Daily grazing time of dairy cows is recorded accurately using the Lifecorder Plus device. Appl. Anim. Behav. Sci. 165:25-32. https://doi.org/10.1016/j.applanim .2015.01.014.

Fielding, A. H., and J. F. Bell. 1997. A review of methods for the assessment of prediction errors in conservation presence/absence models. Environ. Conserv. 24:38-49. https://doi.org/10.1017/ S0376892997000088.

Fisher, A. D., N. Roberts, S. J. Bluett, G. A. Verkerk, and L. R. Matthews. 2008. Effects of shade provision on the behaviour, body temperature and milk production of grazing dairy cows during a New Zealand summer. N. Z. J. Agric. Res. 51:99-105. https://doi .org/10.1080/00288230809510439.

Gibb, M. J., C. A. Huckle, and R. Nuthall. 1998. Effect of time of day on grazing behaviour by lactating dairy cows. Grass Forage Sci. 53:41-46. https://doi.org/10.1046/j.1365-2494.1998.00102.x.

Gregorini, P., M. Eirin, R. Refi, M. Ursino, O. E. Ansin, and S. A. Gunter. 2006. Timing of herbage allocation in strip grazing: Effects on grazing pattern and performance of beef heifers. J. Anim. Sci. 84:1943-1950. https://doi.org/10.2527/jas.2005-537.

Hinkle, D. E., W. Wiersma, and S. G. Jurs. 2003. Applied Statistics for Behavioural Sciences. 5th ed. Houghton Mifflin, Boston, MA.

Kilgour, R. J. 2012. In pursuit of "normal": A review of the behavior of cattle at pasture. Appl. Anim. Behav. Sci. 138:1-11. https://doi .org/10.1016/j.applanim.2011.12.002.

Kull, J. A., K. L. Proudfoot, G. M. Pighetti, J. M. Bewley, B. F. O'Hara, K. D. Donohue, and P. D. Krawczel. 2019. Effects of acute lying and sleep deprivation on the behavior of lactating dairy cows. PLoS One 14:e0212823. https://doi.org/10.1371/journal.pone .0212823 .

Langford, F. M., K. M. D. Rutherford, L. Sherwood, M. C. Jack, A. B. Lawrence, and M. J. Haskell. 2011. Behavior of cows during and after peak feeding time on organic and conventional dairy farms in the United Kingdom. J. Dairy Sci. 94:746-753. https://doi.org/10 .3168/jds.2010-3309.

Lin, L. I.-K. 1989. A concordance correlation coefficient to evaluate reproducibility. Biometrics 45:255-268. https://doi.org/10.2307/ 2532051

Müller, R., and L. Schrader. 2003. A new method to measure behavioural activity levels in dairy cows. Appl. Anim. Behav. Sci. 83:247-258. https://doi.org/10.1016/S0168-1591(03)00141-2.

Nielsen, P. P. 2013. Automatic registration of grazing behaviour in dairy cows using 3D activity loggers. Appl. Anim. Behav. Sci. 148:179-184. https://doi.org/10.1016/j.applanim.2013.09.001.

Pereira, G. M., B. J. Heins, and M. I. Endres. 2018. Validation of an ear-tag accelerometer sensor to determine rumination, eating, and activity behaviors of grazing dairy cattle. J. Dairy Sci. 101:24922495. https://doi.org/10.3168/jds.2016-12534.

Pérez-Ramírez, E., J. Peyraud, and R. Delagarde. 2009. Restricting daily time at pasture at low and high pasture allowance: Effects on pasture intake and behavioral adaptation of lactating dairy 
cows. J. Dairy Sci. 92:3331-3340. https://doi.org/10.3168/jds.2008 $-1951$.

Poulopoulou, I., C. Lambertz, and M. Gauly. 2019. Are automated sensors a reliable tool to estimate behavioural activities in grazing beef cattle? Appl. Anim. Behav. Sci. 216:1-5. https://doi.org/10 .1016/j.applanim.2019.04.009.

Reiter, S., G. Sattlecker, L. Lidauer, F. Kickinger, M. Öhlschuster, W. Auer, V. Schweinzer, D. Klein-Jöbstl, M. Drillich, and M. Iwersen. 2018. Evaluation of an ear-tag-based accelerometer for monitoring rumination in dairy cows. J. Dairy Sci. 101:3398-3411. https://doi .org/10.3168/jds.2017-12686.

Roca-Fernández, A. I., C. P. Ferris, and A. Gonzalez-Rodriguez. 2013. Short communication: Behavioural activities of two dairy cow genotypes (Holstein-Friesian vs. Jersey $\times$ Holstein-Friesian) in two milk production systems (grazing vs. confinement). Span. J. Agric. Res. 11:120-126. https://doi.org/10.5424/sjar/2013111-2682.

Ruuska, S., S. Kajava, M. Mughal, N. Zehner, and J. Mononen. 2016. Validation of a pressure sensor-based system for measuring eating: Rumination and drinking behaviour of dairy cattle. Appl. Anim. Behav. Sci. 174:19-23. https://doi.org/10.1016/j.applanim.2015.11 .005 .

SAS Institute. 2016. SAS/STAT Software. Release 9.4. SAS Institute Inc., Cary, NC.

Steeneveld, W., and H. Hogeveen. 2015. Characterization of Dutch dairy farms using sensor systems for cow management. J. Dairy Sci. 98:709-717. https://doi.org/10.3168/jds.2014-8595.

USDA. 2016. Dairy 2014: Dairy Cattle Management Practices in the United States, 2016. National Animal Health Monitoring System publication no. 692.0216. USDA, Animal and Plant Health Inspec- tion Service (APHIS), Veterinary Services (VS), and Center for Epidemiology and Health (CEAH), Fort Collins, CO.

Werner, J., L. Leso, C. Umstatter, J. Niederhauser, E. Kennedy, A. Geoghegan, L. Shalloo, M. Schick, and B. O'Brien. 2018. Evaluation of the RumiWatchSystem for measuring grazing behaviour of cows. J. Neurosci. Methods 300:138-146. https://doi.org/10.1016/ j.jneumeth.2017.08.022.

Werner, J., C. Umstatter, L. Leso, E. Kennedy, A. Geoghegan, L. Shalloo, M. Schick, and B. O'Brien. 2019. Evaluation and application potential of an accelerometer-based collar device for measuring grazing behavior of dairy cows. Animal 13:2070-2079. https:// doi.org/10.1017/S1751731118003658.

Wolfger, B., E. Timsit, E. A. Pajor, N. Cook, H. W. Barkema, and K. Orsel. 2015. Technical note: Accuracy of an ear tag-attached accelerometer to monitor rumination and feeding behavior in feedlot cattle. J. Anim. Sci. 93:3164-3168. https://doi.org/10.2527/jas .2014-8802.

Zehner, N., C. Umstätter, J. J. Niederhauser, and M. Schick. 2017. System specification and validation of a noseband pressure sensor for measurement of ruminating and eating behavior in stablefed cows. Comput. Electron. Agric. 136:31-41. https://doi.org/10 .1016/j.compag.2017.02.021.

\section{ORCIDS}

G. M. Pereira @ https://orcid.org/0000-0002-2955-0749

B. J. Heins $\odot$ https://orcid.org/0000-0003-2186-9082 


\section{APPENDIX}

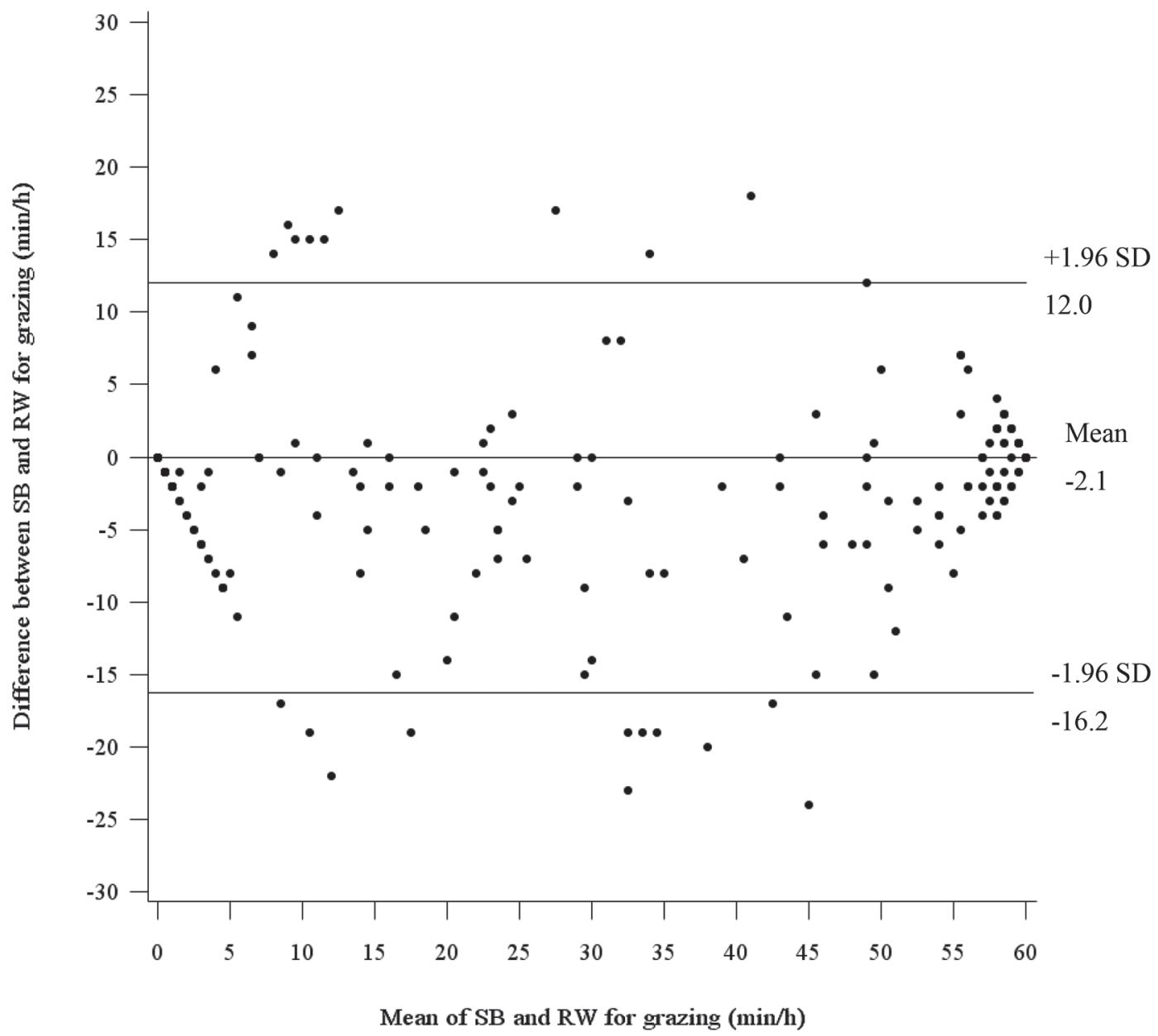

Figure A1. Agreement between Smartbow ear tag (SB; Smartbow GmbH, Weibern, Austria) and the RumiWatch noseband sensor (RW; Itin + Hoch GmbH, Liestal, Switzerland) for grazing in Minnesota $(\mathrm{n}=248)$. The $\mathrm{x}$-axis shows mean values for grazing $(\mathrm{min} / \mathrm{h})$ of $\mathrm{SB}$ and RW and the $\mathrm{y}$-axis shows the difference in values for grazing $(\mathrm{min} / \mathrm{h})$ between $\mathrm{SB}$ and $\mathrm{RW}(\mathrm{SB}-\mathrm{RW})$. The middle line indicates the zero line and outer lines indicate the lower and upper $95 \%$ CI. 


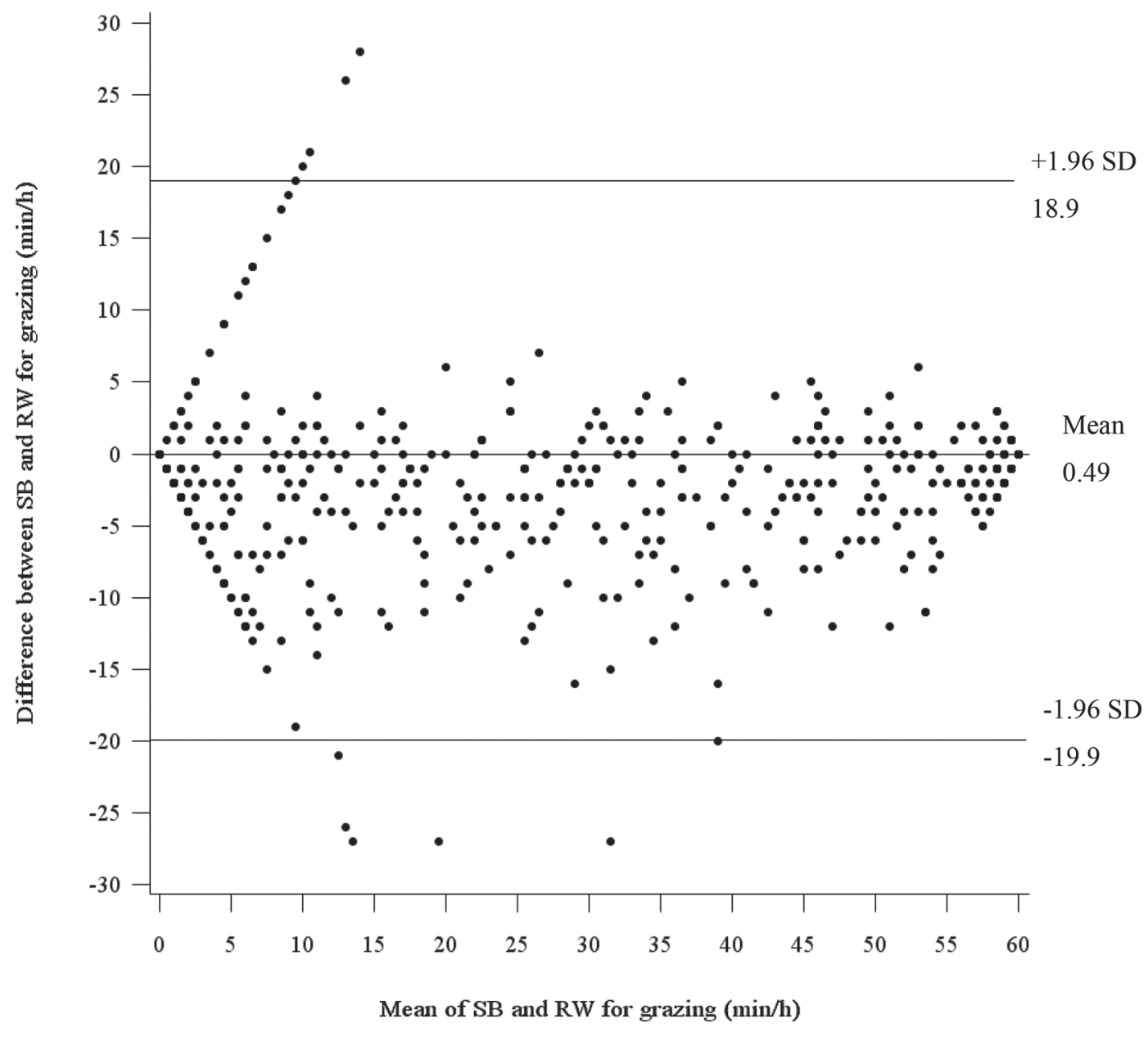

Figure A2. Agreement between Smartbow ear tag (SB; Smartbow GmbH, Weibern, Austria) and the RumiWatch noseband sensor (RW; Itin + Hoch $\mathrm{GmbH}$, Liestal, Switzerland) for grazing in Ireland $(\mathrm{n}=778)$. The $\mathrm{x}$-axis shows mean values for grazing $(\mathrm{min} / \mathrm{h})$ of SB and RW and the $\mathrm{y}$-axis shows the difference in values for grazing $(\mathrm{min} / \mathrm{h})$ between $\mathrm{SB}$ and $\mathrm{RW}(\mathrm{SB}-\mathrm{RW})$. The middle line indicates the zero line and outer lines indicate the lower and upper 95\% CI. 


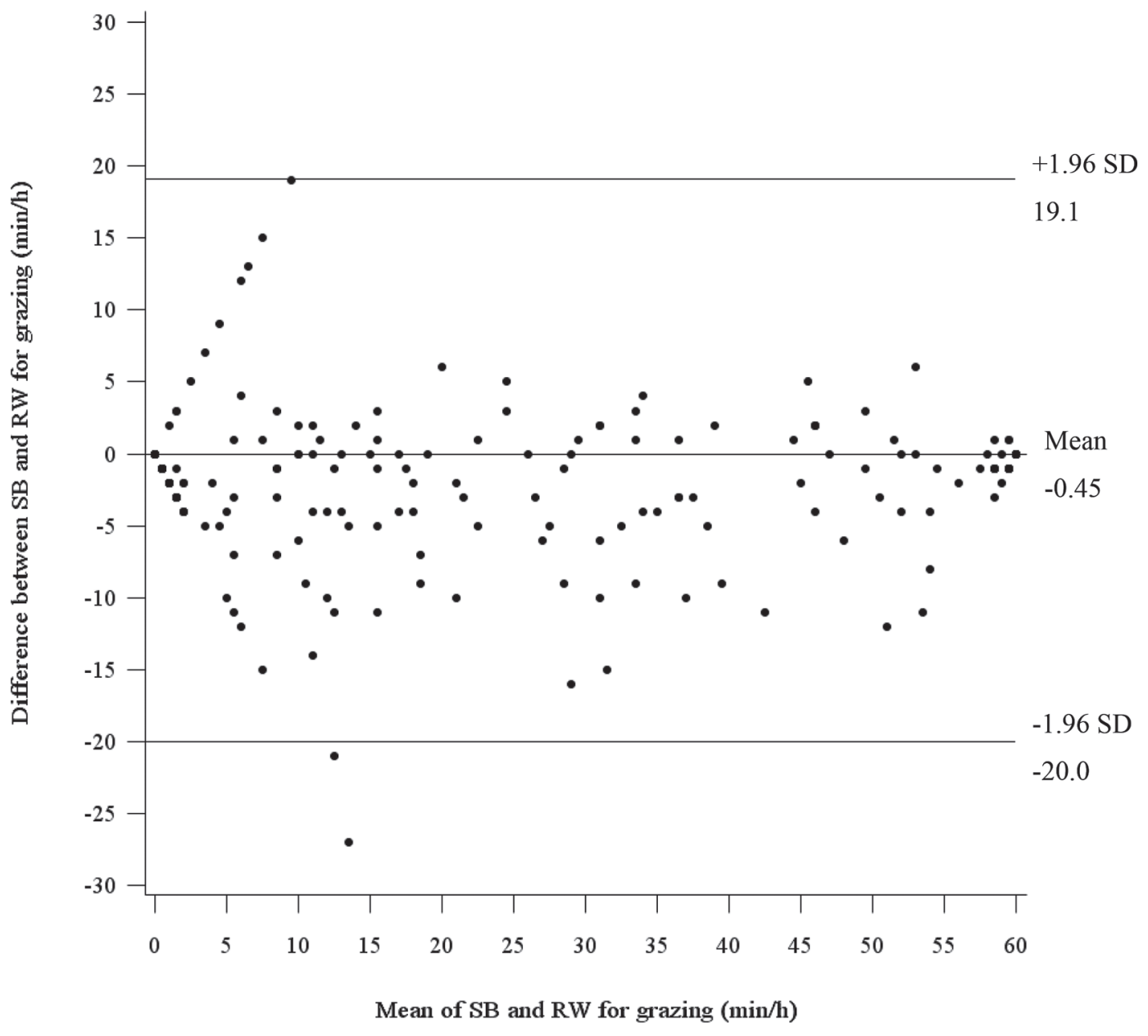

Figure A3. Agreement between Smartbow ear tag (SB; Smartbow GmbH, Weibern, Austria) and the RumiWatch noseband sensor (RW; Itin + Hoch GmbH, Liestal, Switzerland) for grazing in Ireland ( $\mathrm{n}=248$ data set 1$)$. The $\mathrm{x}$-axis shows mean values for grazing (min/h) of SB and RW and the y-axis shows the difference in values for grazing (min/h) between SB and RW (SB - RW). The middle line indicates the zero line and outer lines indicate the lower and upper $95 \%$ CI. 


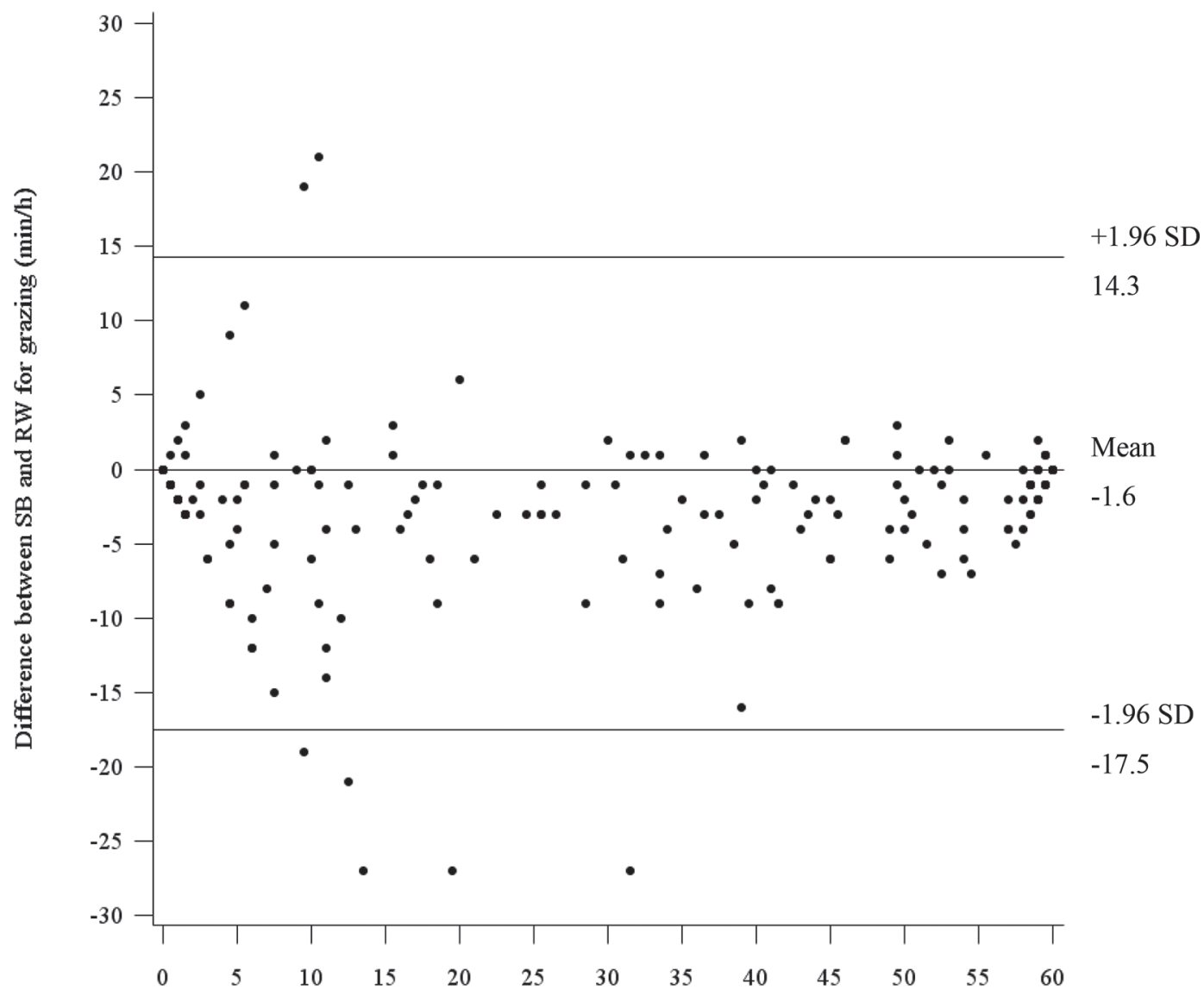

Mean of SB and RW for grazing $(\mathrm{min} / \mathrm{h})$

Figure A4. Agreement between Smartbow ear tag (SB; Smartbow GmbH, Weibern, Austria) and the RumiWatch noseband sensor (RW; Itin + Hoch GmbH, Liestal, Switzerland) for grazing in Ireland $(\mathrm{n}=248$ data set 2$)$. The $\mathrm{x}$-axis shows mean values for grazing (min/h) of SB and RW and the y-axis shows the difference in values for grazing ( $\mathrm{min} / \mathrm{h}$ ) between SB and RW ( $\mathrm{SB}-\mathrm{RW}$ ). The middle line indicates the zero line and outer lines indicate the lower and upper $95 \% \mathrm{CI}$ 


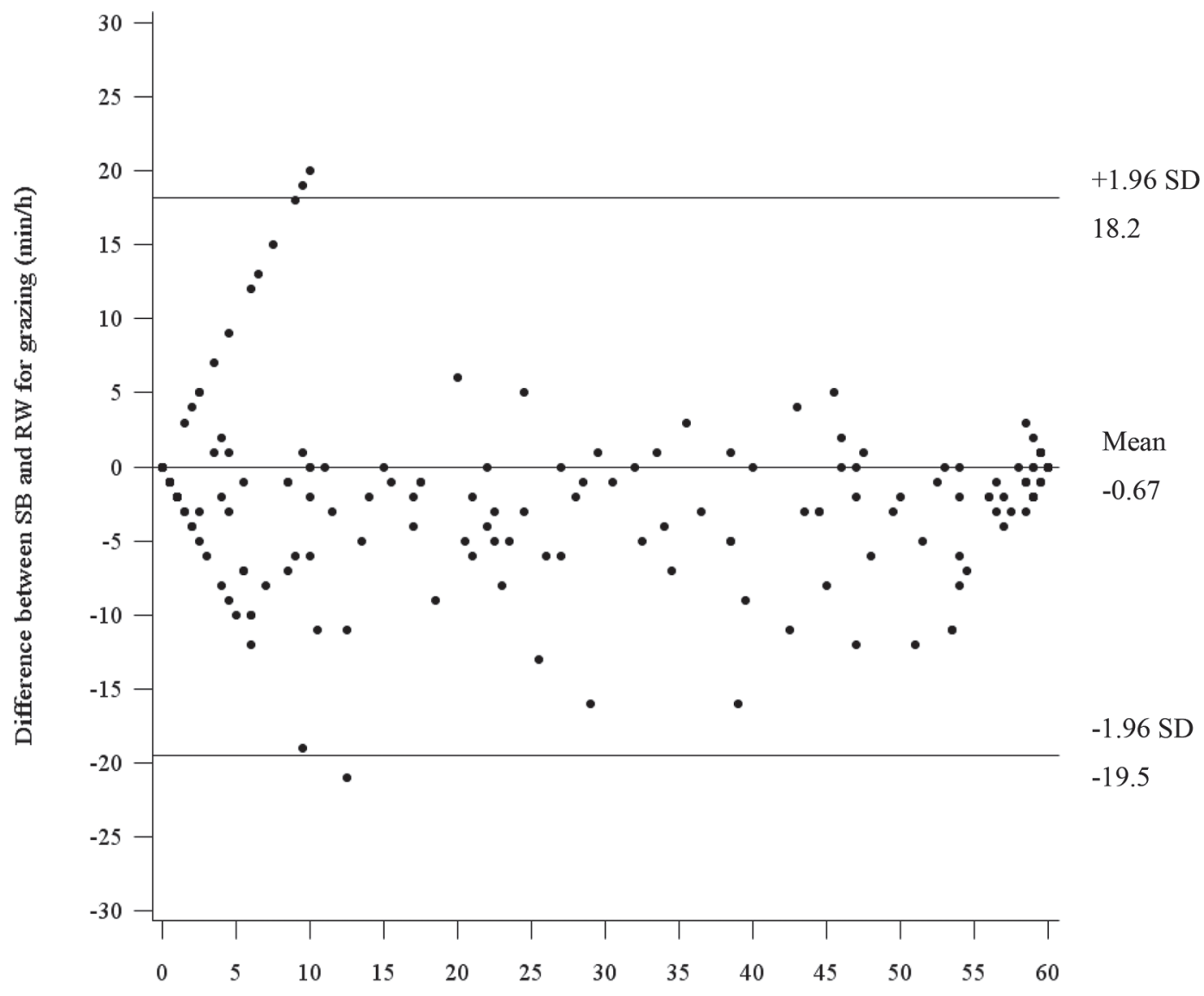

Mean of SB and RW for grazing $(\mathrm{min} / \mathrm{h})$

Figure A5. Agreement between Smartbow ear tag (SB; Smartbow GmbH, Weibern, Austria) and the RumiWatch noseband sensor (RW; Itin + Hoch GmbH, Liestal, Switzerland) for grazing in Ireland $(\mathrm{n}=248$ data set 3$)$. The $\mathrm{x}$-axis shows mean values for grazing (min/h) of SB and RW and the $\mathrm{y}$-axis shows the difference in values for grazing (min/h) between SB and RW (SB - RW). The middle line indicates the zero line and outer lines indicate the lower and upper 95\% CI. 